\title{
Steam Gasification of Different Brown Coals Catalysed by the Naturally Occurring Calcium Species
}

\author{
Peter N. Kuznetsov, Svetlana M. Kolesnikova, Ludmila I. Kuznetsova \\ Institute of Chemistry and Chemical Technology, Siberian Branch of Russian Academy of Sciences, Krasnoyarsk, Russia \\ Email:kpn@icct.ru
}

Received October 25, 2012; revised December 28, 2012; accepted January 7, 2013

\begin{abstract}
The effects of the constituents of mineral matter in brown coals from different deposits of Kansk-Achinsk, Lena and from Yallourn Basins on the structural parameters and steam gasification reactivities of respective coal chars at moderate temperature and at low and high pressure were studied in this paper. The data on how the preliminary decationization with diluted hydrochloric, acetic and sulphuric acids affect char gasification reactivities are presented. The importance of surface area and crystallinity of chars and the presence of naturally occurring metals on gasification reactivity is considered. Quantitative correlations between the calcium contents and the extents of gasification are revealed. The gasification results obtained in a flow reactor with steam stream and in an autoclave reactor at high pressure of gaseous products are compared. The catalytic effect of dispersed calcium oxide-carbonate particles produced from the naturally occurring calcium containing carboxylates was shown to be a key factor for char gasification reactivity, the effect in the flow reactor being much larger as compared to that in the autoclave reactor. This was mainly related to different forms of catalytically active calcium species and to the composition of the gaseous reaction mixture.
\end{abstract}

Keywords: Coal; Mineral Matter; Steam Gasification; Calcium; Catalysis

\section{Introduction}

Gasification is one of the most important multipurpose and efficient technologies to convert coal to energy carriers and to a large variety of valuable products, such as synthetic natural gas, synthesis gas, hydrogen, ammonia, methanol, hydrocarbons and also various carbon materials, catalyst support and sorbents [1]. Coal gasification will continue to play an important role in the foreseeable future. However, this process results in the emissions of greenhouse gases and a variety of air pollutants including $\mathrm{SO}_{\mathrm{x}}, \mathrm{NO}_{\mathrm{x}}$, and large amount of ash. Ultrafine particulates and trace metals emitted from coal are potentially carcinogenic. Therefore efforts must be intensified in the short term to better understand the key factors affecting coal gasification reactions and to develop advanced technologies for clean coal utilization with higher efficiency and near-zero emissions.

It is known that different ranked coals can be gasified successfully by using an appropriate technology. However, the reactivity of coals has been shown [2-6] to tend to decrease with an increase in the rank. The application of catalysts allows coal reactivity to be increased significantly [2-11]. The following sequence of activity of alkali and alkaline-earth metal catalysts for steam gasification of subbituminous coal char was found: $\mathrm{K}_{2} \mathrm{CO}_{3}>$ $\mathrm{Na}_{2} \mathrm{CO}_{3}>\mathrm{KCl}>\mathrm{NaCl}>\mathrm{CaCl}_{2} \sim \mathrm{CaO}$ [7]. Also, other metal species, such as $\mathrm{Mg}, \mathrm{Ba}, \mathrm{Fe}, \mathrm{Ni}, \mathrm{Mn}$ can catalyse the gasification reaction [8-10].

Many researchers [3,4,6,8,11-17] studied the effects of the mineral matter naturally occurring in the coals on the gasification reaction. Miura and Hashimoto et al. [3] reviewed in details a large body of the literature data for the reactivities of coal chars for gasification with $\mathrm{H}_{2} \mathrm{O}$, $\mathrm{CO}_{2}$ and $\mathrm{O}_{2}$ to understand the controlling factors of reaction. The authors concluded that the gasification rates of chars from low rank coals can be affected by mineral components such as these containing $\mathrm{Ca}, \mathrm{K}, \mathrm{Na}, \mathrm{Fe}$ and $\mathrm{Mg}$ acting as the gasification catalysts. Partial demineralization of coals resulted in decrease in the gasification rates by factors of 5 to 25 as compared to that of respective parent coals $[11,13,14]$. However, an anomalous increase in $\mathrm{H}_{2} \mathrm{O}, \mathrm{CO}_{2}$ and air gasification reactivity was obtained when the high volatile bituminous coal has been demineralized with acids [18].

It should be noted that the correlations between the content of specific metals and char gasification reactivity were generally revealed by using the coals (or chars) doped with metals. The authors [4] attempted to correlate gasification conversions of a large number of coals with the specific naturally occurring inorganic constituents. It was reported that though inorganic matter affects conversions during gasification, the systematic patterns re- 
garding the effect of specific metals in coals were difficult to correlate quantitatively. The effects of impregnated salts on $\mathrm{CO}_{2}$ gasification reactivity changed with reaction pressure and coal type in a specific manner. Hence catalysis by mineral matters has not always been found to provide adequate explanation of the gasification kinetics. One should not assume the metals to only catalyse reactions if for no other reason than that they can affect the physical structure and consequently the reactivity of char $[19,20]$.

Because of the complexity of the reactions involved, detailed characterization of coal and char composition, crystallinity and morphology of organic matter, and quantifying their effects on reaction rates is crucial for accurate modeling of gasification systems and for determining key factors. There are currently insufficient data available on the relationships between the coals and the development of char structure.

The comparative experimental investigation of the composition, structural characteristics and gasification behaviour of a suite of the chars produced from different brown coals to find the quantitative correlations was performed in this paper. The effects of the composition of mineral matter on the specific surface area and crystallinity of chars and on their reactivities for steam gasification under atmosphere and high pressure in two experimental reactors were studied. The brown coals from the large Kansk-Achinsk and Lena basins were used. KanskAchinsk brown coals are of particular interest for gasification because of rather low contents of mineral matter in which calcium is abundant $[21,22]$. It has been reported [23-25] that these are Ca cations which contribute a major effect to cross-linking of the organic matter of brown coals resulting in suppressed reactivity for hydrogenation. On the other hand, calcium species affected significantly [26] the properties of steam activated carbons. A sample of brown coal from Yallourn deposit in Australia was also used for comparison, since it contains little inorganic matter which is mainly occurring in the form of metal ions [27].

\section{Experimental}

\subsection{Coals}

The brown coal samples from the Borodino and Berezovo deposits of Kansk-Achinsk Basin, Kangalas deposit of Lena Basin and a sample of brown coal from Yallourn deposit in Australia were studied. The coals were crushed, and a required fraction of $0.5-1.0 \mathrm{~mm}$ dried in a vacuum drying oven at $85^{\circ} \mathrm{C}$ was used.

\subsection{Acid Treatment of Coals}

Selected coal samples were treated with deluted acid aqueous solutions to remove the specific metal cations and to identify their effects on the properties of respective chars. Hydrochloric, sulfuric, and acetic acid sulutions of $0.1,0.2$ and $1.0 \mathrm{~N}$ concentrations were used. An approximately $200 \mathrm{~g}$ dried coal sample was treated in 21 of aqueous acid solutions in a glass flask (filled with an inert gas) with continuous stirring using a magnetic stirrer at room temperature. In $3 \mathrm{~h}$, the solution was decanted, and the treatment with the fresh portion of acid solution was repeated. Then the coal was filtered off, thoroughly washed with distilled water and dried in a vacuum oven at $85^{\circ} \mathrm{C}$.

\subsection{Pyrolysis and Gasification Procedures}

The coals were pyrolyzed in a quartz reactor of $20 \mathrm{~mm}$ in diameter. Weighed dried coal $(15 \mathrm{~g})$ was placed into the reactor which was then closed (not hermetically for the gases to be allowed to escape) and heated at a controlled rate of $7^{\circ} \mathrm{C}-8^{\circ} \mathrm{C} / \mathrm{min}$. The pyrolysis was carried out at the temperature of $700^{\circ} \mathrm{C}$ for $1 \mathrm{~h}$.

The steam gasification of char produced was carried out at relatively low temperature $700^{\circ} \mathrm{C}$ by using two experimental units equipped with a quartz flow tubular reactor and with an autoclave reactor. The tubular reactor of $20 \mathrm{~mm}$ in diameter was charged with $5 \mathrm{~g}$ of char and heated at the rate of $5^{\circ} \mathrm{C} / \mathrm{min}$ under nitrogen flow $(2.5$ $1 / \mathrm{h}$ ). On attaining the reaction temperature of $700^{\circ} \mathrm{C}$, the water feeding $(20 \mathrm{~g} / \mathrm{h})$ was added to nitrogen flow and gasification was carried out for $45 \mathrm{~min}$ at atmospheric pressure.

The autoclave unit was equipped with five $90 \mathrm{~cm}^{3}$ stainless steel autoclaves inserted into a rotated heated sand-bath. Each autoclave was charged with $3 \mathrm{~g}$ of char and $4 \mathrm{~g}$ of distilled water. The autoclaves were purged with nitrogen from the air and hermetically sealed. The heating rate was $7^{\circ} \mathrm{C}-8^{\circ} \mathrm{C} / \mathrm{min}$ and the speed of rotation $90 \mathrm{rev} / \mathrm{min}$. The reaction was carried out at $700^{\circ} \mathrm{C}$ for $2 \mathrm{~h}$ under autogenous pressure of water vapour and gaseous products generated. Then the autoclaves were allowed to cool and the gaseous products were analysed by a gas chromatograph. This autoclave unit allowed thus five char samples to be tested simultaneously under strictly the same conditions. Carbon burn-off was evaluated based on the quantity of organic matter in the char before and after gasification.

\subsection{Coal and Char Characterization}

The composition of coals was characterized by proximate and ultimate analysis. The separate coal samples (both the parent and acid treated) were subjected to oxygen-containing functional group analysis. The content of hydroxyl groups was determined by acetylation in pyridine and the carboxylic oxygen by reaction with calcium acetate and titration of the liberated acetic acid. The con- 
tents of metals were determined by atomic absorption spectrometry and X-ray fluorescence analysis of coal ashes and the data obtained were recalculated based on dry coal.

The phase composition of mineral substances and the structural characterization of the organic matter were monitored by X-ray diffraction. The parameters of the stacking structure of char carbon matter were estimated based on the (002) and (10) bands, the profiles were corrected with adsorption, polarization, and atomic scattering factors according to recommendations described in the references [28-32]. The distance between the aromatic layers $\mathrm{d}_{002}$ in the stacking structure was calculated from the (002) peak position by means of Bragg's equation. The average crystallite thickness $\mathrm{L}_{\mathrm{c}}$ was evaluated from the width at the half maximum of the (002) peak using Scherrer's equation, and the number of aromatic layers $\mathrm{n}$ in the stacks by means of the Equation $\left(\mathrm{L}_{\mathrm{c}} / \mathrm{d}_{002}\right)$ +1 . The average diameter of layers $L_{a}$ was evaluated from the width at the half maximum of the (10) peak. The XRD patterns of powdered char samples packed into aluminium holder were recorded under strictly the same conditions by using a DRON-3 diffractometer with $\mathrm{CuKa}$ radiation and a step-scanning method $\left(\Delta 2 \theta=0.2^{\circ}, 25\right.$ $\mathrm{s} /$ step) between $2 \theta$ from 8 and $55^{\circ}$. The calculated relative crystallite dimensions were sufficiently reliable to monitor the difference in gross-molecular structure of carbon in the chars produced from different coals.

The BET surface areas of chars were measured by low temperature nitrogen adsorption using ASAP 2020 and GCH-1 analizators.

\section{Results and Discussion}

\subsection{Coal Characterization}

Shown in Table $\mathbf{1}$ are the list of the brown coal samples from different deposits and the characterization of their mineral matters. The content of ash ranged from 1.4 to $14.8 \mathrm{wt} \%$. The parent coals showed large variations in the concentration of $\mathrm{Ca}$ (from 0.15 to $1.80 \mathrm{wt} \%$ ), which prevailed in most of the coals alongside the silicon and aluminium. The concentrations of $\mathrm{Mg}$ were less than that of $\mathrm{Ca}$ by a factor of $2-8$, with the exception of Yallourn coal which featured almost equal weight amount of $\mathrm{Mg}$ and $\mathrm{Ca}$. The contents of Fe varied from 0.06 to $0.55 \mathrm{wt} \%$. The alkali metals ( $\mathrm{Na}$ and $\mathrm{K}$ ) occurred in very low concentrations: $0.15 \mathrm{wt} \%$ in Kangalas coal, $0.06 \mathrm{wt} \%$ in Yallourn coal and near 0.01 in Kansk-Achinsk coals [24].

The amounts of most minor elements in Borodino and Berezovo coals were much less than that for coal Clarke numbers (i.e. the average content in the world's coals), except for the alkaline earth $\mathrm{Sr}$ and $\mathrm{Ba}$, and also for $\mathrm{Mn}$ $[22,24]$, showing a typical feature of Kansk-Achinsk brown coal.

The treatment with the acid solutions decreased the ash content by a factor of $1.2-6.0$ depending on the coal samples (Table 1). The alkali cations and alkaline earth

Table 1. The characterization of mineral matters of brown coals from different deposits.

\begin{tabular}{|c|c|c|c|c|c|}
\hline \multirow{2}{*}{$\begin{array}{l}\text { Coal deposit } \\
\text { sample }\end{array}$} & \multirow{2}{*}{ Treatment } & \multirow{2}{*}{$\begin{array}{c}\mathrm{Ad} \\
\mathrm{wt} \%\end{array}$} & \multicolumn{3}{|c|}{ Content, wt $\%$ on daf coal } \\
\hline & & & $\mathrm{Ca}$ & $\mathrm{Mg}$ & $\mathrm{Fe}$ \\
\hline \multicolumn{6}{|l|}{ Parent coals } \\
\hline Borodino, Bor $_{1}$ & No & 4.1 & 0.80 & 0.10 & 0.10 \\
\hline Borodino, Bor $_{2}$ & No & 6.5 & 1.25 & 0.30 & 0.06 \\
\hline Borodino, Bor $_{3}$ & No & 7.7 & 1.22 & 0.20 & 0.08 \\
\hline Borodino, Bor $_{4}$ & No & 5.4 & 1.08 & - & - \\
\hline Borodino, Bor $_{5}$ & No & 4.4 & 1.30 & 0.10 & 0.10 \\
\hline 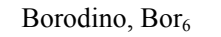 & No & 5.3 & 1.13 & 0.30 & 0.15 \\
\hline Borodino, Bor $_{7}$ & No & 4.9 & 0.73 & 0.19 & 0.18 \\
\hline Borodino, Bor $_{21}$ & No & 4.9 & 1.20 & 0.19 & 0.18 \\
\hline Borodino, Bor $_{22}$ & No & 4.2 & 1.80 & 0.45 & 0.46 \\
\hline Borodino, Bor $_{23}$ & No & 14.8 & 1.43 & 0.80 & 0.23 \\
\hline Berezovo, Ber $_{9}$ & No & 4.3 & 1.40 & 0.20 & 0.50 \\
\hline Kangalas, $\mathrm{Ka}_{20}$ & No & 7.9 & 1.22 & 0.20 & 0.44 \\
\hline Yallourn, $\mathrm{Ya}_{10}$ & No & 1.4 & 0.15 & 0.16 & 0.40 \\
\hline \multicolumn{6}{|l|}{ Acid-treated coals } \\
\hline Borodino, Bor $_{2} \mathrm{D}$ & $0.2 \mathrm{~N} \mathrm{HCl}$ & 3.3 & 0.003 & $\leq 10-5$ & 0.03 \\
\hline Borodino, Bor $_{3} \mathrm{D}$ & $0.2 \mathrm{~N} \mathrm{HCl}$ & 4.8 & $\leq 0.0004$ & $\leq 10-5$ & 0.02 \\
\hline Borodino, Bor $_{5} \mathrm{D}$ & $0.2 \mathrm{~N} \mathrm{HCl}$ & 1.1 & $\leq 0.0001$ & $\leq 10-5$ & 0.01 \\
\hline Borodino, Bor $_{6} \mathrm{D}$ & $0.2 \mathrm{~N} \mathrm{HCl}$ & 1.3 & $\leq 0.001$ & $\leq 10-5$ & 0.01 \\
\hline Borodino, Bor $_{22} \mathrm{D}$ & $0.1 \mathrm{~N} \mathrm{HCl}$ & 0.9 & 0.009 & 0.0009 & 0.138 \\
\hline Borodino, Bor $_{22} \mathrm{D}$ & $1.0 \mathrm{~N} \mathrm{HCl}$ & 0.7 & 0.004 & 0.0005 & 0.008 \\
\hline Borodino, Bor $_{22} \mathrm{D}$ & $1.0 \mathrm{~N} \mathrm{H}_{2} \mathrm{SO}_{4}$ & 1.0 & 0.07 & 0.001 & 0.015 \\
\hline Borodino, Bor $_{22} \mathrm{D}$ & $1.0 \mathrm{~N} \mathrm{CH}_{3} \mathrm{COOH}$ & 1.7 & 0.04 & 0.002 & 0.46 \\
\hline Borodino, Bor $_{23} \mathrm{D}$ & $1.0 \mathrm{~N} \mathrm{HCl}$ & 12.6 & 0.015 & не обн. & 0.035 \\
\hline Berezovo, $\mathrm{Ber}_{9} \mathrm{D}$ & $0.2 \mathrm{~N} \mathrm{HCl}$ & 0.8 & $\leq 0.0001$ & $\leq 10-5$ & 0.004 \\
\hline
\end{tabular}


metals $\mathrm{Mg}$ and $\mathrm{Ca}$ were almost completely removed by $\mathrm{HCl}, \mathrm{H}_{2} \mathrm{SO}_{4}$ and $\mathrm{CH}_{3} \mathrm{COOH}$ solutions. Also the cations of minor elements such as $\mathrm{Mn}, \mathrm{V}, \mathrm{Be}, \mathrm{Y}$ and $\mathrm{Yb}$ readily passed into $\mathrm{HCl}$ solution (95\% and more) [24]. The recovery of $\mathrm{Fe}$ varied from 50 to $93 \%$ when coals were treated with $\mathrm{HCl}$ and $\mathrm{H}_{2} \mathrm{SO}_{4}$ solutions, however no $\mathrm{Fe}$ was removed with $1 \mathrm{~N} \mathrm{CH}_{3} \mathrm{COOH}$ solution.

The data in Table 2 show rather close elemental composition of organic matter of representative coal samples, with the exceptions of Yallourn coal, which features a lowered carbon content and increased oxygen content, and of Kangalas coal with enhanced hydrogen content. The nitrogen and sulphur contents were near to 0.8 and $0.3 \%$ in all the samples, respectively. $\mathrm{HCl}$ treatment hardly affects significantly the ultimate analysis data of coals [24].

Shown in Table 3 are the contents of hydroxyl and carboxyl groups in the representative parent and in the respective acid treated coals. It is seen that the coals differed moderately with the content of hydroxyl groups (in the range of $4.1-5.32 \mathrm{mg}$-equiv per $1 \mathrm{~g}$ of daf coal). On the other hand, the parent coals differed remarkably from each other with the content of free acids (from 0.78 to $2.06 \mathrm{mg}$-equiv./g). Acid treatment affected moderately and nonregularly the content of hydroxyls, however, greatly increased the content of free acids (by $1.2-2.3$ times depending on coal samples). Both parent and acid treated Yallourn coal samples show an increased hydroxyl and carboxyl groups due to the increased total oxygen content.

It is known that alkali and alkaline earth metallic species (mainly $\mathrm{Na}, \mathrm{Mg}$ and $\mathrm{Ca}$ ) can exist in the brown coals

Table 2. Ultimate analysis data for representative brown coal samples.

\begin{tabular}{|c|c|c|c|c|c|}
\hline \multirow{2}{*}{ Coal sample } & \multicolumn{5}{|c|}{$\mathrm{Wt} \%$ on daf coal } \\
\hline & $\mathrm{C}$ & $\mathrm{H}$ & $\mathrm{N}$ & S & $\mathrm{O}$ \\
\hline Borodino, Bor $_{1}$ & 69.7 & 4.9 & 0.8 & 0.3 & 24.3 \\
\hline Borodino, Bor $_{2}$ & 70.8 & 4.8 & 0.8 & 0.3 & 23.3 \\
\hline Borodino, Bor $_{3}$ & 71.3 & 4.8 & 0.9 & 0.2 & 22.8 \\
\hline Borodino, Bor $_{6}$ & 70.0 & 4.8 & 0.8 & 0.2 & 24.2 \\
\hline Borodino, Bor $_{21}$ & 71.9 & 4.6 & 0.7 & 0.3 & 22.1 \\
\hline Borodino, Bor $_{22}$ & 71.4 & 5.4 & 0.8 & 0.2 & 22.1 \\
\hline Borodino, Bor $_{23}$ & 69.3 & 5.2 & 0.7 & 0.3 & 23.9 \\
\hline Berezovo, Ber 9 & 70.1 & 4.9 & 0.9 & 0.3 & 23.8 \\
\hline Kangalas, $\operatorname{Kan}_{20}$ & 71.0 & 5.5 & 0.8 & 0.4 & 21.8 \\
\hline Yallourn, $\mathrm{Ya}_{10}$ & 66.6 & 4.7 & 0.6 & 0.3 & 27.8 \\
\hline Borodino, Bor ${ }_{6} \mathrm{D}(0.2 \mathrm{HCl})$ & 71.3 & 4.9 & 0.8 & 0.3 & 22.7 \\
\hline
\end{tabular}

Table 3. The data on oxygen functional analysis of the parent and HCl treated brown coal samples (mg-equiv./g coal).

\begin{tabular}{|c|c|c|c|c|c|c|}
\hline \multirow{2}{*}{ Coal sample } & \multicolumn{3}{|c|}{ Parent coals } & \multicolumn{3}{|c|}{ Acid treated coals } \\
\hline & $\mathrm{OH}$ & $\mathrm{COOH}$ & $\mathrm{Ca}$ & $\mathrm{OH}$ & $\mathrm{COOH}$ & $\Delta \mathrm{COOH}^{*}$ \\
\hline Borodino, Bor $_{2}$ & 4.06 & 0.87 & 0.62 & 4.40 & 1.72 & 0.85 \\
\hline Borodino, Bor $_{3}$ & 4.10 & 1.12 & 0.61 & 4.34 & 1.91 & 0.79 \\
\hline Borodino, Bor 5 & 4,80 & 1.03 & 0.65 & 4.50 & 1.72 & 0.69 \\
\hline 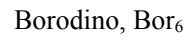 & 5.09 & 1.22 & 0.56 & 4.71 & 1.76 & 0.54 \\
\hline Borodino, Bor $_{7}$ & 4.50 & 1.37 & 0.36 & 4.82 & 1.78 & 0.41 \\
\hline Borodino, Bor $_{22}$ & 4.70 & 0.91 & 0.90 & 4.38 & 1.87 & 0.96 \\
\hline Borodino, Bor $_{23}$ & 4.95 & 1.03 & 0.71 & 4.63 & 1.84 & 0.81 \\
\hline Berezovo, Ber 9 & 5.00 & 0.78 & 0.70 & 4.90 & 1.81 & 1.03 \\
\hline Yallourn, $\mathrm{Ya}_{10}$ & 5.18 & 2.06 & 0.08 & 5.32 & 2.53 & 0.47 \\
\hline
\end{tabular}

"Difference between $\mathrm{COOH}$ contents in the acid treated and in the parent coals.

mainly in two forms: as ion-exchangeable cations associated mainly with the carboxyl groups of the organic coal matter or in the forms of soluble and insoluble minerals. This aspect of metal forms is both attractive and interesting to understand the role of metal species in the chemical reaction of organic matter.

The treatment of brown coals with deluted acids $(\mathrm{HCl}$, $\mathrm{H}_{2} \mathrm{SO}_{4}$ and acetic acid) resulted in the exhaustive extraction of the alkali and alkaline earth metallic species, calcium being predominant in all the coals, except for Yallourn coal. As regards Kansk-Achinsk coals, the previous systematic investigations $[24,33,34]$ have documented calcium to occur predominantly in the organic matter in the ion-exchangeable form of the carboxylate complexes. In Table 3, the contents of calcium cations (in mg-equiv. quantity) in the parent coals are shown also in order to compare quantitatively the reaction stoichiometry. One can see that the increase in the number of $\mathrm{COOH}$ groups as a result of acid treatment is nearly equal or slightly more than the quantity of calcium extracted. Some excess in increase in the number of $\mathrm{COOH}$ may be due to the fact that it has been not considered some contribution of other cations $\left(\mathrm{Mg}^{2+}\right.$, in the first place). The data confirm thus again that in the coals studied, calcium occurs predominantly in the form of carboxylate complexes. Only little or no calcium minerals (calcite, in the first place) may occur in the parent coals though they were not visible by XRD. It should be noted, however, that calcite, sulfate and other calcium based minerals can be found in the parent brown coals when containing higher amount of ash, for example, in the heavy part of brown coal after its benefication.

\subsection{Coal Carbonization}

The char yields from the pyrolysis of the parent and acid 
treated Kansk-Achinsk coals varied from 53 to $62 \%$ and those from Kangalas and Yallourn coals did 50\% (Table 4). BET surface areas of chars produced from the parent and acid treated coals ranged from 35 to $262 \mathrm{~m}^{2} / \mathrm{g}$, and Yallourn char showed much larger surface area of 425 $\mathrm{m}^{2} / \mathrm{g}$.

The X-ray diffraction patterns of the coals and respective chars were obtained to identify the minerals and to characterize the structural composition of organic matter. Predominantly quartz with different quantities was detected in the XRD patterns. No distinct reflections related to other mineral species (such as calcite) were reliably observed and identified because of probably low content, low crystallinity, or high dispersion.

The XRD patterns showed typical broad asymmetrical

Table 4. The characterization of chars produced on pyrolysis of different brown coals at $700^{\circ} \mathrm{C}$.

\begin{tabular}{|c|c|c|c|c|}
\hline \multirow{2}{*}{$\begin{array}{l}\text { Char } \\
\text { Bor }_{1}\end{array}$} & \multicolumn{2}{|c|}{$\mathrm{A}^{\mathrm{d}}, \mathrm{wt} \% \mathrm{Ca}, \mathrm{wt} \%$} & \multicolumn{2}{|c|}{$\begin{array}{l}\text { Char yield, BET surface area, } \\
\mathrm{wt} \% \text { on daf } \mathrm{m}^{2} / \mathrm{g} \text { on daf char }\end{array}$} \\
\hline & 6.9 & 1.40 & 57 & 140 \\
\hline Bor $_{2}$ & 11.2 & 2.27 & 55 & 224 \\
\hline Bor $_{3}$ & 12.9 & 2.12 & 57 & 74 \\
\hline Bor $_{4}$ & 8.7 & 1.80 & 60 & 118 \\
\hline Bor $_{5}$ & 7.4 & 2.45 & 53 & 140 \\
\hline Bor $_{6}$ & 8.6 & 1.91 & 59 & 77 \\
\hline Bor $_{7}$ & 6.8 & 1.30 & 56 & 262 \\
\hline Bor $_{21}$ & 7.9 & 2.03 & 59 & 262 \\
\hline Bor $_{22}$ & 6.9 & 2.8 & 64 & 162 \\
\hline Bor $_{23}$ & 23.3 & 2.3 & 62 & 239 \\
\hline Ber $_{9}$ & 7.5 & 2.55 & 55 & 180 \\
\hline $\mathrm{Ka}_{20}$ & 14.7 & 2.44 & 50 & 49 \\
\hline $\mathrm{Ya}_{10}$ & 2.8 & 0.30 & 50 & 425 \\
\hline $\mathrm{Bor}_{2} \mathrm{D}(0.2 \mathrm{HCl})$ & 5.3 & 0.005 & 61 & 120 \\
\hline $\mathrm{Bor}_{3} \mathrm{D}(0.2 \mathrm{HCl})$ & 7.7 & 0.002 & 59 & - \\
\hline $\mathrm{Bor}_{5} \mathrm{D}(0.2 \mathrm{HCl})$ & 1.4 & 0.002 & 56 & 114 \\
\hline Bor $_{6} \mathrm{D}(0.2 \mathrm{HCl})$ & 2.1 & 0.002 & 60 & 156 \\
\hline Bor $_{22} \mathrm{D}(0.1 \mathrm{~N} \mathrm{HCl})$ & 1.9 & 0.02 & 53 & 42 \\
\hline Bor $_{22} \mathrm{D}(1.0 \mathrm{~N} \mathrm{HCl})$ & 1.4 & 0.008 & 50 & 35 \\
\hline $\begin{array}{c}\operatorname{Bor}_{22} \mathrm{D} \\
\left(1.0 \mathrm{~N} \mathrm{H}_{2} \mathrm{SO}_{4}\right)\end{array}$ & 2.0 & 0.137 & 51 & 46 \\
\hline $\begin{array}{c}\mathrm{Bor}_{22} \mathrm{D} \\
\left(1.0 \mathrm{~N} \mathrm{CH}_{3} \mathrm{COOH}\right)\end{array}$ & 2.7 & 0.06 & 62 & 71 \\
\hline Bor $_{23} \mathrm{D}(1.0 \mathrm{~N} \mathrm{HCl})$ & 19.8 & 0.03 & 58 & 101 \\
\hline $\mathrm{Ber}_{9} \mathrm{D}(0.2 \mathrm{HCl})$ & 1.4 & 0.002 & 55 & 220 \\
\hline
\end{tabular}

reflection in the $2 \theta$ region from $8^{\circ}$ to $34^{\circ}$ due to a specific inter-molecular ordering of carbon matter and to a weak reflection with a maximum centered at $2 \theta$ of about $44^{\circ}$ due to intra-molecular ordering (10 reflection). It was shown by using the computer treatment that broad asymmetrical reflection attributed to inter-molecular ordering can be well simulated by a superposition of two Gaussians (Figure 1). According to the references [2831 ], they were referred to ordered carbon portion in which polyaromatic molecules are stacked in parallel $(2 \theta$ reflection centered at $23.0^{\circ}-24.5^{\circ}$ ) and to disordered other molecules of $\gamma$-component located at the periphery of the polyaromatic clusters $\left(2 \theta\right.$ centered at $\left.19^{\circ}-21^{\circ}\right)$ and not included in the stacking structure [28,29]. Large broadening of the 002 reflection and 10 reflection is interpreted in terms of small dimensions of crystallites. The small crystallites of stacked polyaromatics and the disordered other molecules represent the crystallite and noncrystallite char components, respectively, and their combination forms char microtexture. The proportion between the content of these two structures was evaluated based on the areas of the respective Gaussian peaks.

The structural parameters evaluated from the X-ray diffraction patterns are summarized in Table 5. One can see that the chars from the parent coals consist of mainly crystallites $(74 \%-93 \%)$ with a small portion $(7 \%-26 \%)$ of disordered $\gamma$-component. On the other hand, acid trea-

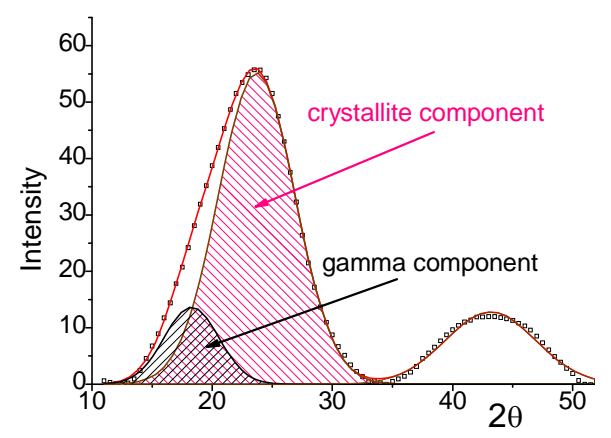

(a)

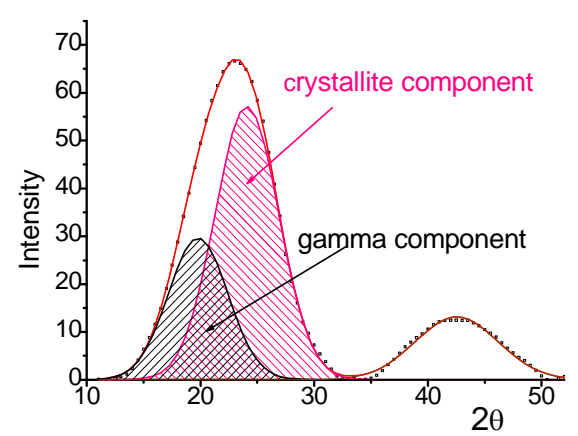

(b)

Figure 1. The fragments of the typical $X$-ray diffraction patterns for the chars from the parent (a) and from the 0.2 N HCl treated brown coals (b). 
ted chars differ with less content of crystallites $(60 \%$ $72 \%)$ and with the increased portion of $\gamma$-component (28\% - 40\%).

The polyaromatic layers in the stacks in all the chars have the diameters mainly from 1.57 to $1.95 \mathrm{~nm}$ (with the occasional exceptions) with the average statistical value of $1.69 \pm 0.10 \mathrm{~nm}$ and inter-layer spacing of 0.379 $\pm 0.009 \mathrm{~nm}$ (Table 5). The thicknesses of the stacks $\mathrm{L}_{\mathrm{c}}$ range from $1.01 \mathrm{~nm}$ to $1.37 \mathrm{~nm}$ depending on the char sample, the chars from the parent coals having the stacks consisted of $3.6-4.1$ polyaromatic layers. The acid treated chars consist of stacks with $\mathrm{L}_{\mathrm{c}}$ of $1.01-1.22 \mathrm{~nm}$ and 4.2 - 4.8 number of layers.

No regular correlations were found between the specific surface areas, X-ray structural parameters and the composition of coals, such as proximate and ultimate analytical data and the contents of specific metals.

Table 5. The proportion between the X-ray structural carbon portions and structural parameters for the crystallites of chars produced from different brown coals.

\begin{tabular}{|c|c|c|c|c|c|c|}
\hline Coal char & \multicolumn{2}{|c|}{ Proportion, \% } & $\mathrm{d}_{002}$ & Number & $\mathrm{L}_{\mathrm{c}}$ & $\mathrm{L}_{\mathrm{a}}$ \\
\hline & \multicolumn{2}{|c|}{$\begin{array}{l}\text { Crystallite } \\
\text { component }\end{array}$} & $\mathrm{nm}$ & of layers & $\mathrm{nm}$ & $\mathrm{nm}$ \\
\hline \multicolumn{7}{|l|}{$\begin{array}{l}\text { From parent } \\
\text { coals }\end{array}$} \\
\hline Bor $_{1}$ & 79 & 21 & 0.391 & 3.9 & 1.15 & 1.70 \\
\hline Bor $_{2}$ & 88 & 12 & 0.392 & 3.6 & 1.04 & 1.71 \\
\hline Bor $_{3}$ & 83 & 17 & 0.379 & 4.0 & 1.14 & 1.57 \\
\hline Bor $_{4}$ & 74 & 26 & 0.383 & 3.7 & 1.04 & 1.57 \\
\hline Bor $_{5}$ & 84 & 16 & 0.379 & 3.9 & 1.09 & 1.69 \\
\hline Bor $_{6}$ & 80 & 20 & 0.375 & 4.0 & 1.12 & 1.61 \\
\hline Bor $_{7}$ & 89 & 11 & 0.375 & 3.9 & 1.10 & 1.64 \\
\hline Bor $_{22}$ & 85 & 15 & 0.390 & 3.8 & 1.08 & 1.95 \\
\hline $\mathrm{Ber}_{9}$ & 93 & 7 & 0.373 & 3.7 & 1.01 & 1.82 \\
\hline $\mathrm{Kan}_{20}$ & 78 & 22 & 0.367 & 4.0 & 1.11 & 1.65 \\
\hline $\mathrm{Ya}_{10}$ & 80 & 20 & 0.388 & 4.1 & 1.22 & 1.84 \\
\hline \multicolumn{7}{|l|}{$\begin{array}{l}\text { From } \mathrm{HCl} \\
\text { treated coals }\end{array}$} \\
\hline Bor $_{2} \mathrm{D}$ & 60 & 40 & 0.379 & 4.3 & 1.25 & 1.68 \\
\hline Bor $_{3} \mathrm{D}$ & 61 & 39 & 0.393 & 4.5 & 1.37 & 1.61 \\
\hline Bor $_{5} \mathrm{D}$ & 72 & 28 & 0.373 & 4.4 & 1.28 & 1.75 \\
\hline Bor $_{6} \mathrm{D}$ & 64 & 36 & 0.372 & 4.2 & 1.21 & 1.63 \\
\hline $\begin{array}{l}\text { Bor }{ }_{22} \mathrm{D}\left(\mathrm{H}_{2} \mathrm{SO}_{4}\right. \\
\text { treated })\end{array}$ & 72 & 28 & 0.370 & 4.6 & 1.33 & 2.24 \\
\hline $\mathrm{Ber}_{9} \mathrm{D}$ & 63 & 37 & 0.361 & 4.8 & 1.36 & 2.08 \\
\hline
\end{tabular}

\subsection{Char gasification}

\subsubsection{Gasification in Flow Reactor}

Shown in Table 6 are the data on char gasification in a flow tubular reactor at $700^{\circ} \mathrm{C}$ for $45 \mathrm{~min}$ reaction period. One can see that the extents of burn-off of the chars produced from the parent coals changed from 27.8 to $67.3 \%$ $\mathrm{wt} \%$ on a dry ash-free basis, and the chars from the acid treated coals showed much less burn-offs $(2.9 \%-11.3 \%)$. For example, the burn-off of char produced from Bor $_{22}$ coal treated with $1.0 \mathrm{~N} \mathrm{HCl}$ solution was as low as $3.2 \%$ that contrasted with $67.3 \%$ for char from the parent Bor $_{22}$ coal. As the gasification time of this $\mathrm{HCl}$ treated char was increased to $150 \mathrm{~min}$ (i.e., by a factor of $>3$ ), the burn-off extent increased to only $9.0 \%$. The $\mathrm{CH}_{3} \mathrm{COOH}$ treated sample showed slightly higher reactivity $(11.3 \%)$ as compared to the samples treated with $\mathrm{HCl}$ and $\mathrm{H}_{2} \mathrm{SO}_{4}$ acids $(3.2 \%-6.2 \%)$, however much less then that of the parent one. Last column in Table 5 shows how the chars differed from each other with the extents of burn-off normalized to the unit surface areas. One can see that the surface normalized burn-off for chars from the parent coals vary from 0.23 to $0.42 \mathrm{wt} \% / \mathrm{m}^{2}$, and the acid treated chars show much less values (from 0.09 to $0.16 \mathrm{wt} \%$ / $\mathrm{m}^{2}$ ).

A rational explanation for the differences in the surface normalized reactivities of chars is the reaction to occur not on total carbon surface area but only on the surface in the immediate vicinity of mineral species which can act as a catalyst. To clarify which species were more important in determining the reactivity, the correlations between the burn-off and mineral matter com-

Table 6. Steam gasification of chars from different coals for $45 \mathrm{~min}$ at $700^{\circ} \mathrm{C}$ in flow reactor. Water feeding of $20 \mathrm{~g} / \mathrm{h}$, nitrogen flow of $2.5 \mathrm{l} / \mathrm{h}$.

\begin{tabular}{|c|c|c|c|}
\hline Char & $\begin{array}{l}A^{d} \text { of char } \\
\text { residue, wt } \%\end{array}$ & $\begin{array}{l}\text { Burn-off, } \\
\mathrm{wt} \% \text { on daf }\end{array}$ & $\begin{array}{c}\text { Burn-off per unit } \\
\text { surface area, } \mathrm{wt} \% / \mathrm{m}^{2} \text { daf }\end{array}$ \\
\hline $\mathrm{Bor}_{3}$ & 18.1 & 27.8 & 0.38 \\
\hline Bor $_{21}$ & 12.6 & 37.6 & 0.38 \\
\hline Bor $_{22}$ & 18.7 & 67.3 & 0.42 \\
\hline Bor $_{23}$ & 39.7 & 54.6 & 0.23 \\
\hline $\begin{array}{c}\text { Bor }_{22} \mathrm{D} \\
(0.1 \mathrm{~N} \mathrm{HCl})\end{array}$ & 1.85 & 5.3 & 0.12 \\
\hline $\begin{array}{c}\text { Bor }_{22} \mathrm{D} \\
(1.0 \mathrm{~N} \mathrm{HCl})\end{array}$ & 1.55 & 3.2 & 0.09 \\
\hline $\begin{array}{c}\operatorname{Bor}_{22} \mathrm{D} \\
\left.1.0 \mathrm{~N} \mathrm{H}_{2} \mathrm{SO}_{4}\right)\end{array}$ & 2.1 & 6.2 & 0.14 \\
\hline $\begin{array}{c}\mathrm{Bor}_{22} \mathrm{D}(1.0 \mathrm{~N} \\
\left.\mathrm{CH}_{3} \mathrm{COOH}\right)\end{array}$ & 3.1 & 11.3 & 0.16 \\
\hline $\begin{array}{c}\text { Bor }_{23} \mathrm{D} \\
(1.0 \mathrm{~N} \mathrm{HCl})\end{array}$ & 20.8 & 7.6 & 0.09 \\
\hline
\end{tabular}


position were analysed. The comparison of the data on gasification in Table 6 and on the mineral matter contents in Table 1 showed no correlations. A certain correlation was observed (with the determination coefficient of $\mathrm{R}^{2}=0.84$ ) when the values for surface normalized carbon burn-off were plotted versus the content of calcium only (Table 4). However, good correlation (with the determination coefficient of $\mathrm{R}^{2}=0.95$ ) proved to take place between the carbon burn-off based on wt $\%$ daf char and the content of calcium (Figure 2):

Burn-off extent, wt $\%=6.2-6.7 \mathrm{Ca}+10.3 \mathrm{Ca}^{2} ; \mathrm{R}^{2}=$ 0.95 .

This correlation suggests the reactivity of brown coal chars for steam gasification to be affected in some way mainly by calcium species in agreement with most of the previous works $[8,9,11,16,17]$. Other metals, such as $\mathrm{Mg}$ and Fe, could affect the reaction. However their effects were not evident because of probably less contents and lower specific activities as compared to those of calcium. For example, $\mathrm{CH}_{3} \mathrm{COOH}$ solution extracted calcium almost completely from Bor $_{22}$ coal, but no extraction of iron was observed (Table 1). The char produced was much less reactive as compared to the char from the parent coal (11.3 and 67.2\%, respectively, Table 6).

Displayed in Table 7 are the gasification data obtained in the autoclave reactor at $700^{\circ} \mathrm{C}$ for $2 \mathrm{~h}$. The extents of carbon burn-off ranged from 18.4 to $31.8 \mathrm{wt} \%$ and the total yields of gaseous products from 23.3 to $61.0 \mathrm{wt} \%$ based on dry ash-free chars. Again, acid treated chars showed less reactivities as compared to those produced from the parent coals. The accumulation of gaseous products gradually increased the pressure in the autoclave (up to 11 - $13 \mathrm{MPa}$ at the reaction conditions) depending on carbon burn-off. Good correlations were observed between the values of carbon burn-off and gas-

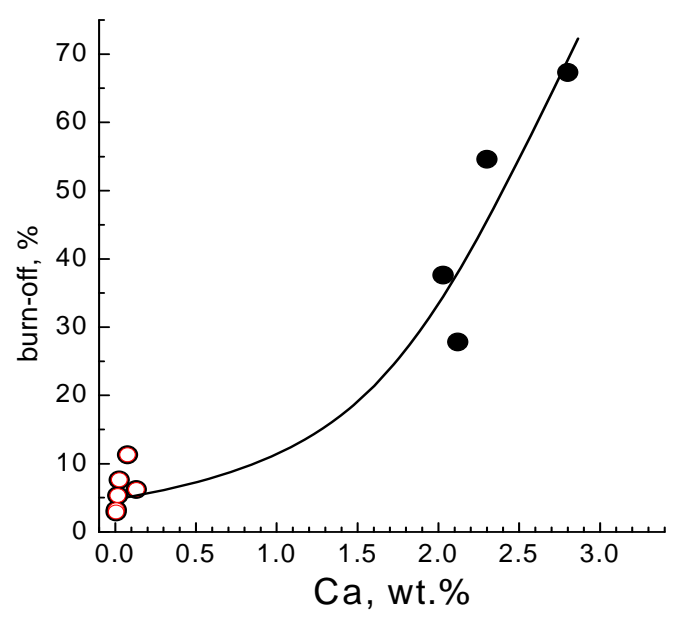

Figure 2. Carbon burn-off dependant on calcium content in the chars. Flow reactor. Dark symbols - chars from parent coals; open symbols - from HCl treated coals.
Table 7. Steam gasification of chars from different coals at $700^{\circ} \mathrm{C}$ in the autoclave reactor.

\begin{tabular}{ccccc}
\hline Char & $\mathrm{A}^{\mathrm{d}}, \mathrm{wt} \%$ & $\begin{array}{c}\text { Burn-off, } \\
\mathrm{wt} \% \text { on daf }\end{array}$ & $\begin{array}{c}\text { Gas yield, } \\
\mathrm{wt} \% \text { on daf }\end{array}$ & $\begin{array}{c}\text { Gas yield, } \\
\mathrm{wt} \% / \mathrm{m}^{2} \text { daf }\end{array}$ \\
\hline Bor $_{1}$ & 6.8 & 27.0 & 48.3 & 0.34 \\
Bor $_{2}$ & 11.2 & 27.4 & 51.6 & 0.23 \\
Bor $_{3}$ & 12.9 & 30.2 & 54.9 & 0.74 \\
Bor $_{4}$ & 8.7 & 28.1 & 52.0 & 0.44 \\
Bor $_{5}$ & 7.4 & 28.0 & 54.2 & 0.39 \\
Bor $_{6}$ & 8.6 & 29.7 & 55.5 & 0.72 \\
Bor $_{7}$ & 6.8 & 26.5 & 54.5 & 0.21 \\
Bor $_{21}$ & 8.4 & 26.3 & 54.0 & 0.55 \\
Ber $_{9}$ & 7.5 & 31.8 & 61.0 & 0.34 \\
Kan $_{20}$ & 14.6 & 26.9 & 55.1 & 1.11 \\
Ya $_{10}$ & 2.8 & 20.2 & 34.7 & 0.08 \\
Bor $_{2} \mathrm{D}(0.2 \mathrm{HCl})$ & 5.2 & 20.0 & 31.2 & 0.26 \\
$\mathrm{Bor}_{3} \mathrm{D}(0.2 \mathrm{HCl})$ & 7.6 & 18.5 & 23.3 & 0.22 \\
$\mathrm{Bor}_{5} \mathrm{D}(0.2 \mathrm{HCl})$ & 1.4 & 18.4 & 28.8 & 0.25 \\
$\mathrm{Bor}_{6} \mathrm{D}(0.2 \mathrm{HCl})$ & 2.1 & 20.9 & 34.5 & 0.22 \\
$\mathrm{Ber}_{9} \mathrm{D}(0.2 \mathrm{HCl})$ & 1.4 & 19.3 & 33.5 & 0.15 \\
\hline
\end{tabular}

yield. The values of burn-off measured based on the quantity of organic matter in the char before and after gasification and by measuring the carbon content in the carbonaceous gases were also well corroborated.

One can see from Table 7 that again the extents of char gasification were quite insensitive to the total surface areas. For example, Yallourn char with the largest surface area showed least reactivity as compared to other parent chars with much less surface area. Up to 14 fold difference (from 0.08 to $1.11 \mathrm{wt} \% / \mathrm{m}^{2}$ ) is observed between the surface normalized reactivities which correlate too weakly to the contents of calcium. On the other hand, $\mathrm{HCl}$ treated chars showed rather close reactivities.

Not all surface carbon atoms are well known [3,35-38] to have the same reactivity for gasification because of structural defects and differences in the strain energy within the carbon network besides the effects of catalytic species on the carbon surface. Carbon atoms out of the crystallites show usually higher specific reactivity and are easily gasified as compared to those in the crystallites.

It follows from the comparison of the XRD structural parameters of organic matter in Table 5 and gasification reactivities in Table 7 that relatively ordered chars from the parent coals with only $11 \%-26 \%$ of disordered $\gamma$-fraction proved to show higher extents of burn-off than 
less ordered acid treated chars enriched with $28 \%-40 \%$ of $\gamma$-fraction. This may mean that structural properties (surface area and crystallinity) of carbon matter of chars could hardly control steam gasification reactivities under the given conditions.

From the data in Tables 1 and 7, fairly good correlations between the values for carbon burn-off and gas yield based on daf wt. and the content of calcium with the determination coefficients of $\mathrm{R}^{2}=0.89$ and 0.92 were revealed (Figure 3):

Carbon burn-off, $w t^{\%}=19.2+7.2 \mathrm{C}_{\mathrm{Ca}}-1.4 \mathrm{C}_{\mathrm{Ca}}{ }^{2} ; \mathrm{R}^{2}=$ 0.89 ;

Gas yield, $w t \%=29.5+18.2 \mathrm{C}_{\mathrm{Ca}}-3,5 \mathrm{C}_{\mathrm{Ca}}^{2} ; \mathrm{R}^{2}=0,92$.

Some deviations from the correlation curves in Figure 3 can arise from difference in the forms and dispersions of calcium species and/or from nonuniform distribution within the organic matter of char. Also, other metals, such as iron and magnesium could contribute to catalysis of the reaction. However their effects were no evidently because of probably less contents and lower specific catalytic activities as compared to those of calcium.

\subsubsection{The Composition of Gaseous Products}

The composition of the gaseous products was dependent on coal chars. The gaseous autoclave products consisted of mainly $\mathrm{CO}_{2}(32-37 \mathrm{~mol} \%), \mathrm{H}_{2}(20-29 \mathrm{~mol} \%)$, and $\mathrm{CH}_{4}$ (31 - $\left.41 \mathrm{~mol} \%\right)$ with least amount of $\mathrm{CO}(1 \%-2 \%)$. Figure 4 shows the yields of $\mathrm{CO}_{2}$ and also of $\mathrm{H}_{2}$ to correlate with $\mathrm{Ca}$ contents:

1) $\mathrm{CO}_{2}$ yield $(\mathrm{mmol} / \mathrm{g})=3.07+1.16 \mathrm{C}_{\mathrm{Ca}}-0.21 \mathrm{C}_{\mathrm{Ca}}^{2}$; $\mathrm{R}^{2}=0.90$

2) $\mathrm{H}_{2}$ yield $(\mathrm{mmol} / \mathrm{g})=2.14+0.91 \mathrm{C}_{\mathrm{Ca}}-0.13 \mathrm{C}_{\mathrm{Ca}}{ }^{2} ; \mathrm{R}^{2}$ $=0.74$.

It seems reasonable to suggest $\mathrm{CO}_{2}$ and $\mathrm{H}_{2}$ to be originated from the same gross-reaction catalyzed by calcium species:

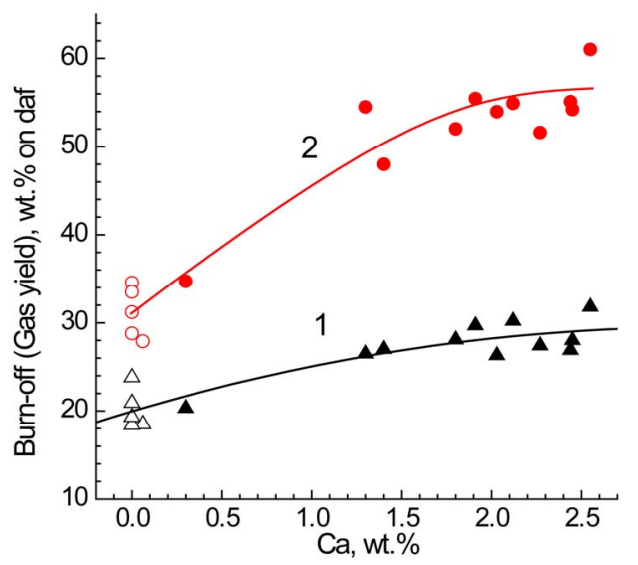

Figure 3. Carbon burn-off (1) and yield of gases (2) dependant on calcium content in the chars. Autoclave reactor. Dark symbols - chars from parent coals; open symbolsfrom $\mathrm{HCl}$ treated coals.

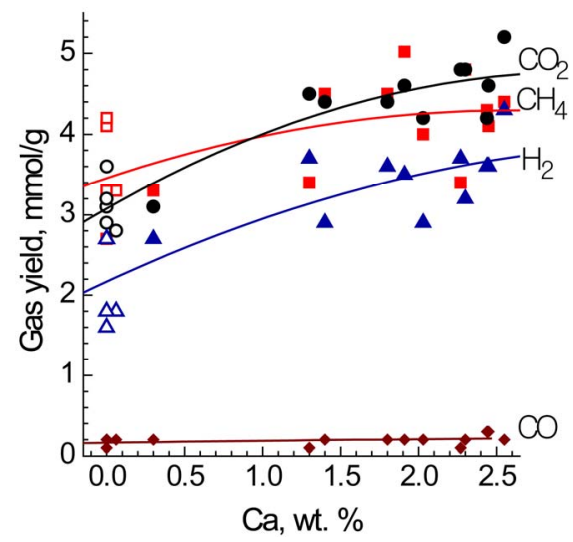

Figure 4. The yields of gaseous products dependant on the calcium content in the chars. Autoclave reactor.

$$
\begin{aligned}
& \mathrm{C}+\mathrm{H}_{2} \mathrm{O}=\mathrm{CO}+\mathrm{H}_{2} \\
& \mathrm{CO}+\mathrm{H}_{2} \mathrm{O}=\mathrm{CO}_{2}+\mathrm{H}_{2}
\end{aligned}
$$

However, the actual $\mathrm{H}_{2}$ yields were much less than those of $\mathrm{CO}_{2}$ in consideration of stoichiometry of reactions. This could result from partial hydrogen consumption in a methane generation reaction. However, large scatter for methane yields with no distinct trend and with too unsatisfactory correlation $\left(\mathrm{R}^{2}=0.34\right)$ is observed in Figure 4, $\mathrm{HCl}$ treated chars yielding essentially same amount of methane as the chars from the parent coals. It follows from this that alkali and alkaline metal species have no relevance to methanation under given conditions. The catalysis of $\mathrm{CO}$ hydrogenation into methane by $\mathrm{Fe}$ species $[2,10]$ can not be excluded, however its effect is difficult to observe because of low Fe concentrations.

The yield of CO was very low in all cases (0.05- 0.3 $\mathrm{mmol} / \mathrm{g}$ ) irrespectively of metal contents. This may mean that water gas shift reaction (2) and $\mathrm{CO}$ hydrogenation reaction occured rapidly under these conditions producing $\mathrm{H}_{2}, \mathrm{CO}_{2}$ and $\mathrm{CH}_{4}$.

\subsubsection{XRD Analysis of Char Residues}

XRD patterns of the char residues after ashing showed complicated mixtures of various crystalline mineral substances. Shown in Figure 5 are the XRD patterns of the ashes from the representative parent coals and also from $\mathrm{HCl}$ treated one, as examples. Major minerals identified in the ashes from Kansk-Achinsk and Kangalas coals were quartz $\left(\alpha-\mathrm{SiO}_{2}\right)$, calcite $\left(\mathrm{CaCO}_{3}\right)$, lime $(\mathrm{CaO})$, anhydrite $\left(\mathrm{CaSO}_{4}\right)$, hematite $\left(\alpha-\mathrm{Fe}_{2} \mathrm{O}_{3}\right), \mathrm{Ca}_{3} \mathrm{Al}_{6} \mathrm{O}_{12}-\mathrm{CaSO}_{4}$, $\mathrm{Ca}(\mathrm{OH})_{2}$ and trace amounts of some other nonidentified minerals. Yallourn coal ash consisted of mainly $\mathrm{FeFe}_{2} \mathrm{O}_{4}$ (may be $\mathrm{MgFe}_{2} \mathrm{O}_{4}$ ), $\mathrm{CaSO}_{4}$ and much less $\mathrm{CaCO}_{3}$ and $\mathrm{CaO}$ species. Mainly $\alpha-\mathrm{SiO}_{2}$, much less $\alpha-\mathrm{Fe}_{2} \mathrm{O}_{3}$ and only trace amount of $\mathrm{CaSO}_{4}$ were detected in the ashes from the $0.1 \mathrm{~N} \mathrm{HCl}$ treated coals. The excess of sulphur 


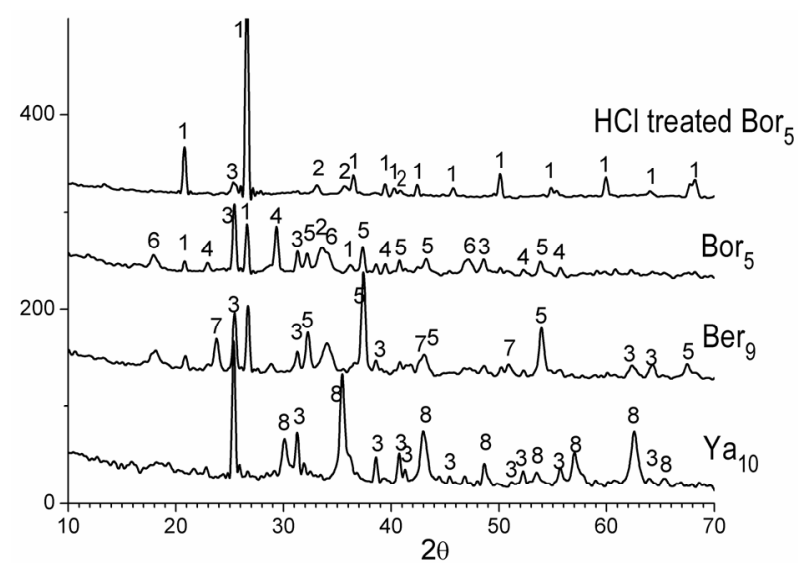

Figure 5. X-ray diffraction patterns of the ashes from the demineralized and parent coal chars. $1-\alpha-\mathrm{SiO}_{2} ; 2-$ $\alpha-\mathrm{Fe}_{2} \mathrm{O}_{3} ; 3-\mathrm{CaSO}_{4} ; 4-\mathrm{CaCO}_{3} ; 5-\mathrm{CaO} ; 6-\mathrm{Ca}(\mathrm{OH})_{2} ; 7-$ $\mathrm{Ca}_{3} \mathrm{Al}_{6} \mathrm{O}_{12} \cdot \mathrm{CaSO} 4 ; 8-\mathrm{FeFe}_{2} \mathrm{O}_{4} \cdot\left(\mathrm{MgFe}_{2} \mathrm{O}_{4}\right)$.

over calcium in the acid treated chars was favorable for the binding of calcium in the form of $\mathrm{CaSO}_{4}$. The sizes of the crystallites of the main $\mathrm{CaCO}_{3}$ and $\mathrm{CaO}$ particles estimated from the width of XRD peaks were less than $30 \mathrm{~nm}$.

\section{Conclusions}

The conclusion should be drawn thus from the results obtained in this study that steam gasification reactivities of chars produced from Kansk-Achinsk, Kangalas and Yallourn brown coals at the moderate temperature of $700^{\circ} \mathrm{C}$ under atmospheric pressure in a flow reactor and under a high pressure of reaction products in the autoclave reactor obey the common regularity controlled by catalysis on the well-dispersed $\mathrm{CaO}$ or/and $\mathrm{CaCO}_{3}$ particles. The latter were produced during the carbonization and gasification steps from the calcium carboxylate derivatives naturally occurring in the brown coals. These nanosized calcium species catalysed gasification mainly into $\mathrm{CO}_{2}$ and $\mathrm{H}_{2}$ gases. The production of $\mathrm{CH}_{4}$ seems to occur by another way irrespectively of calcium species. The structural properties of chars (surface area and crystallinity) hardly affect the gasification reactivity.

However, from the comparison of the gasification behaviors of chars under different reaction conditions, the question may be raised as to why much larger differences between the reactivities of chars from the parent coals and from the respective acid treated ones were obtained in the flow reactor with steam stream at atmospheric pressure as compared to those in the autoclave reactor under high pressure of gaseous products. One reason could be caused by different forms of calcium species produced in different reactors and this can be interpreted in terms of a calcium carbonate - calcium oxide cycle mechanism [8]. Under reaction conditions at $700^{\circ} \mathrm{C}$, a mobile thermodynamic equilibrium between these calcium species is strongly controlled by $\mathrm{CO}_{2}$ pressure. Therefore at the atmospheric pressure in a tubular reactor with the steam in nitrogen flow where the gaseous products were removed continuously, calcium oxide was probably the predominant species that effectively catalysed reaction. On the other hand, calcium carbonate (which are probably catalytically less active as compared to calcium oxide) predominanted during the gasification in the autoclave under high pressure of $\mathrm{CO}_{2}$. Apart from this, the gaseous products $\mathrm{CO}_{2}, \mathrm{H}_{2}$ and $\mathrm{CH}_{4}$ accumulated in the autoclave may inhibit steam gasification due to stronger adsorption and lower specific reactivity $[11,39]$.

The results obtained allow Kansk-Achinsk brown coals to be considered as the preferable and environmentally freindly raw material naturally charged with the precursors of the catalytically active species for effective gasification. The chars derived from the acid treated coals differed with very low gasification reactivities. This fact may be in the way in developing the effective processes for ultraclean gasification of ash-free coals.

\section{Acknowledgements}

This work was supported in part by the Siberian Branch of the Russian Academy of Sciences (Integration Program, Project no. 13).

\section{REFERENCES}

[1] T. A. Adams and P. I. Barton, "Combining coal Gasification and Natural Gas Reforming for Efficient Polygeneration," Fuel Processing Technology, Vol. 92, No. 3, 2011, pp. 639-655. doi:10.1016/j.fuproc.2010.11.023

[2] A. Sharma, T. Takanohashi, K. Morishita, T. Takarada and I. Saito, "Low Temperature Catalytic Steam Gasification of Hyper Coal to Produce $\mathrm{H}_{2}$ and Synthesis Gas," Fuel, Vol. 87, No. 4-5, 2008, pp. 491-497. doi:10.1016/j.fuel.2007.04.015

[3] K. Miura, K. Hashimoto and P. L. Silveston, "Factors Affecting the Reactivity of Coal Chars during Gasification, and Indices Representing Reactivity," Fuel, Vol. 68, No. 11, 1989, pp. 1461-1467. doi:10.1016/0016-2361(89)90046-X

[4] L. Lemaignen, Y. Zhuo, G. P. Reed, D. R. Dugwell and R. Kandiyoty, "Factors Governing Reactivity in Low Temperature Coal Gasification. Part II. An Attempt to Correlate Conversions with Inorganic and Mineral Constituents," Fuel, Vol. 81, No. 3, 2002, pp. 315-326. doi:10.1016/S0016-2361(01)00140-5

[5] I. M. K. Ismail and P. L. Walker, "D.s.c. and TGA Measurements of $\mathrm{O}_{2}$ Interaction with Coal Chars," Fuel, Vol. 68, No. 11, 1989, pp. 1456-1460. doi:10.1016/0016-2361(89)90045-8

[6] T. Takarada, Y. Tamai and A. Tomita, "Reactivities of 34 Coals under Steam Gasification," Fuel, Vol. 64, No. 10, 1985, pp. 1438-1442. doi:10.1016/0016-2361(85)90347-3 
[7] Z.-I. Liu and H.-H. Zhu, "Steam Gasification of Coal Char Using Alkali and Alkaline-Earth Metal Catalysts," Fuel, Vol. 65, No. 10, 1986, pp. 1334-1338. doi:10.1016/0016-2361(86)90099-2

[8] Y. Ohtsuka and A. Tomita, "Calcium Catalysed Steam Gasification of Yallourn Brown Coal," Fuel, Vol. 65, No. 12, 1986, pp. 1653-1657. doi:10.1016/0016-2361(86)90264-4

[9] F. Kapteijn, H. Porre and J. A. Moulijn, " $\mathrm{CO}_{2}$ Gasification of Activated Carbon Catalyzed by Earth Alkaline Elements," AIChE Journal, Vol. 32, No. 4, 1986, pp. 691-695. doi:10.1002/aic.690320421

[10] Y. Ohtsuka, Y. Tamai and A. Tomita, "Iron-Catalyzed Gasification of Brown Coal at Low Temperatures," Fuel and Energy, Vol. 1, No. 1, 1987, pp. 32-36. doi:10.1021/ef00001a006

[11] A. Linares-Solano, E. J. Hippo and P. L. Walker, "Catalytic Activity of Calcium for Lignite Char Gasification in Various Atmospheres," Fuel, Vol. 65, No. 6, 1986, pp. 776-779. doi:10.1016/0016-2361(86)90068-2

[12] C.-Z. Li, "Some Recent Advances in the Understanding of the Pyrolysis and Gasification Behaviour of Victorian Brown Coal," Fuel, Vol. 86, No. 12-13, 2007, pp. 16641683. doi:10.1016/i.fuel.2007.01.008

[13] T. Kyotani, S. Karasawa and A. Tomita, "TPD Study of Coal Chars in Relation to the Catalysis of Mineral Matter," Fuel, Vol. 65, No. 10, 1986, pp. 1466-1469. doi:10.1016/0016-2361(86)90125-0

[14] P. Samaras, E. Diamadopoulos and G. P. Sakellaropoulos, "The Effect of Mineral Matter and Pyrolysis Conditions on the Gasification of Greek Lignite by Carbon Dioxide," Fuel, Vol. 75, No. 9, 1996, pp. 1108-1114. doi:10.1016/0016-2361(96)00058-0

[15] P. J. J. Tromp, F. Kapteijn and J. A. Moulijn, "NATO ASI Series. Series C. Mathematical and Physical Sciences," No. 370, Kluwer, Amsterdam, 1992, p. 84.

[16] K. Matsuoka, T. Yamashita, K. Kuramoto and A. Tomita, "Transformation of Alkali and Alkaline Earth Metals in Low Rank Coal during Gasification," Fuel, Vol. 87, No. 6, 2008, pp. 885-893. doi:10.1016/j.fuel.2007.05.031

[17] K. Mitsuoka, S. Hayashi, H. Amano, K. Kayahara, E. Sasaoka and A. Uddin, "Gasification of Woody Biomass Char with $\mathrm{CO}_{2}$ : The Catalytic Effects of $\mathrm{K}$ and Ca Species on Char Gasification Reactivity," Fuel Processing Technology, Vol. 92, No. 1, 2011, pp. 26-31 doi:10.1016/i.fuproc.2010.08.015

[18] A. Linares-Solano, C. Salinas-Martínez de Lecea, F. Rodríguez-Reinoso and M. Almela-Alarcón “Anomalous' Increase in $\mathrm{CO}_{2}$ Reactivity, Relative to Steam and Air on Acid Treatment of Coals," Fuel, Vol. 65, No. 10, 1986, pp. 1345-1348. doi:10.1016/0016-2361(86)90101-8

[19] S. Zhang, J. I. Hayashi and C.-Z. Li, "Volatilisation and Catalytic Effects of Alkali and Alkaline Earth Metallic Species during the Pyrolysis and Gasification of Victorian Brown Coal. Part IX. Effects of Volatile-Char Interactions on Char- $\mathrm{H}_{2} \mathrm{O}$ and Char- $\mathrm{O}_{2}$ Reactivities," Fuel, Vol. 90, No. 11, 2011, pp. 1655-1661.

[20] C. Sheng, "Char Structure Characterised by Raman Spec- troscopy and Its Correlations with Combustion Reactivity," Fuel, Vol. 86, No. 15, 2007, pp. 2316-2324. doi:10.1016/j.fuel.2007.01.029

[21] D. Yanovsky, V. Sharypov, M. Schipko and P. Kuznetsov, "Pyrolysis and Steam Gasification of Solid Residues from Borodino Coal Hydrogenation," Khimiya Tverdogo Topliva, No. 5, 1989, pp. 77-81 (Rus).

[22] K. V. Gavrilin and A. Yu. Ozerskii, "Kansko-Achinskii ugol'nyi Bassein (Kansk-Achinsk Coal Basin)," Nedra, Moscow, 1996 (Rus).

[23] P. Kuznetsov, "The Chemical Modification, Swelling of Coals, and Reactivity in Hydrogenation," Khimiya Tverdogo Topliva No. 3, 1998, pp. 53-68 (Rus).

[24] P. Kuznetsov and L. Kuznetsova, "Effect of the Mineral Components of Brown Coals on the Properties of Organic Matter in the Interaction with Solvents," Solid Fuel Chemistry, Vol. 42, No. 6, 2008, pp. 372-380.

[25] P. Kuznetsov, L. Kuznetsova, J. Bimer, et al., "Quantitative Relation between the Macromolecular Characteristics of Brown Coal and Its Reactivity in Conversion with Tetralin," Fuel, Vol. 76, No. 2, 1997, pp. 189-193. doi:10.1016/S0016-2361(96)00172-X

[26] P. Kuznetsov, L. Kuznetsova and E. Kutikhina, "Effect of the Decationization of Brown Coal from the KanskAchinsk Basin on the Physicochemical Properties of the Resulting Sorbents," Solid Fuel Chemistry, Vol. 42, No. 3, 2008, pp. 153-159.

[27] D. J. Allardice, L. M. Clemow and W. R. Jackson, "Determination of the Acid Distribution and Total Acidity of Low-Rank Coals and Coal-Derived Materials by an Improved Barium Exchange Technique," Fuel, Vol. 82, No. 1, 2003, pp. 35-40. doi:10.1016/S0016-2361(02)00193-X

[28] M. N. Siddiqiu, M. F. Ali and J. Shirikoff, "Use of X-Ray Diffraction in Using the Aging Pattern of Asphalt Fractions," Fuel, Vol. 81, No. 1, 2002, pp. 51-58. doi:10.1016/S0016-2361(01)00116-8

[29] V. Saranchuk, A. Airuni and K. Kovalev, "Nadmolekulyarnaya Organizatsiya, Struktura i Svoistva Uglya (Supramolecular Organization, Structure, and Properties of Coal)," Naukova Dumka, Kiev, 1988 (Rus).

[30] A. F. Lukovnikov, Yu. M. Korolev, G. S. Golovin, et al., "X-Ray Diffraction of Kuznetsk Coals," Khimiya Tverdogo Topliva, No. 5, 1996, pp. 3-13 (Rus).

[31] H. Takagi, K. Maruyama, N. Yoshizawa, Y. Yamada and Y. Saito, "XRD Analysis If Carbon Stacking Structure in Coal During Heat Treatment," Fuel, Vol. 83, No. 17-18, 2004, pp. 2427-2433. doi:10.1016/j.fuel.2004.06.019

[32] M. Siddiuqui, M. Ali and J. Shorokoff, "Use of X-Ray Diffraction in Assessing the Aging of Asphalt Fractions," Fuel, Vol. 81, No. 1, 2002, pp. 51-58. doi:10.1016/S0016-2361(01)00116-8

[33] E. N. Loskutova, N. M. German, K. I. Bochkareva and K. N. Schiryaeva, "Pyrolysis of Brown Coals," Nauka, Novosibirsk, 1968.

[34] R. Ya. Birgaus and T. A. Kuharenko, "Chemistry and Processing of Fuels," Vol. 27, International Gemological Institute, Moskwa, 1971, pp. 3-12.

[35] J. F. Byrne and H. Marsh, "Introductory Overview," In: J. 
W. Patrick, Ed., Porosity in Carbons: Characterization and Applications, Edward Arnold, London, 1995, pp. 712.

[36] H. Marsh, "The Determination of Surface Areas of Coals-Some Physicochemical Considerations," Fuel, Vol. 44, No. 2, 1965, pp. 253-260.

[37] N. R. Laine, F. J. Vastola and P. L. Walker, "The Importants of Active Surface Area in the Carbon Oxygen Reaction," The Journal of Physical Chemistry, Vol. 67, No. 10,
1963, pp. 2030-2034. doi:10.1021/j100804a016

[38] J. B. Lewis, "Modern Aspects of Graphite Technology," Academic Press, New York, 1970, p. 129.

[39] D. G. Roberts and D. J. Harris, "Char Gasification in Mixtures of $\mathrm{CO}_{2}$ and $\mathrm{H}_{2} \mathrm{O}$ : Competition and Inhibition," Fuel, Vol. 86, No. 17-18, 2007, pp. 2672-2678.

doi:10.1016/j.fuel.2007.03.019 